\title{
Seed Transmission of Acidovorax avenae subsp. citrulli in Cucurbits
}

\author{
D.L. Hopkins ${ }^{1}$ and C.M. Thompson ${ }^{2}$ \\ Mid-Florida Research and Education Center, University of Florida, 2725 \\ Binion Road, Apopka, FL 32703-8504
}

Additional index words. Citrullus lanatus, seedborne bacterium, bacterial fruit blotch

\begin{abstract}
Prevention of the introduction of bacterial fruit blotch of watermelon, caused by Acidovorax avenae subsp. citrulli, into the transplant house or field is the most effective control strategy. Watermelon seedlots currently are screened for A. avenae subsp. citrulli, but other cucurbits, often grown in the same transplant house or field, generally are not as carefully monitored. In 1997 and 1999 field tests, cultivars of watermelon, muskmelon, honeydew melons, acorn squash, butternut squash, yellow squash, zucchini squash, cucumber, and pumpkin were evaluated for foliar and fruit susceptibility to bacterial fruit blotch and for seed transmission of $A$. avenae subsp. citrulli. The bacterium was introduced into the field on infected watermelon transplants or by misting a bacterial suspension onto fruit of the cucurbits. Foliar and fruit symptoms were more extensive in the watermelon, muskmelon, and honeydew melons than in the other cucurbits. In greenhouse grow-out assays, seed transmission of $A$. avenae subsp. citrulli was detected in every cucurbit in at least one of the two seasons, even though there were no fruit symptoms in some of them. Thus, any cucurbit crop plant should be considered a potential source for the introduction of $A$. avenae subsp. citrulli into the transplant house or field.
\end{abstract}

Bacterial fruit blotch (BFB) of watermelon (Citrullus lanatus), caused by Acidovorax avenae subsp. citrulli, was first observed in commercial production areas in the United States in Spring 1989 (Latin and Rane, 1990; Somodi et al., 1991). In some fields, losses were more than $90 \%$ of the total marketable fruit. BFB of watermelon has occurred in one or more watermelon-producing states in the eastern United States every year since 1989 (Maynard and Hopkins, 1999). Severe epidemics developed in Georgia in 1992 and throughout the eastern United States in 1994 (Hopkins et al., 1996). In 1994, thousands of hectares of watermelon in at least 10 states were affected. The characteristic symptom of BFB that renders the fruit unmarketable is the greasy-appearing, water-soaked, dark, olivegreen stain, or blotch, that develops on the upper surface of infected fruit (Latin and Hopkins, 1995). Eventually, the lesions turn brown, crack, and ooze a sticky, amber substance. Secondary organisms invade and rot the fruit. Acidovorax avenae subsp. citrulli also produces symptoms on seedlings and leaves. On seedlings, water-soaked lesions are produced on hypocotyls and cotyledons, sometimes causing collapse and death of the seedling. Leaf lesions usually are relatively inconspicuous and do not result in defoliation, but are most important as reservoirs of bacteria for fruit infection.

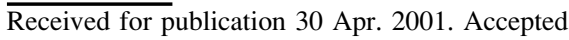
for publication 4 Dec. 2001. Univ. of Florida Agricultural Experiment Station Journal Series Paper No. R-08118.

${ }^{1}$ Professor. To whom requests for reprints should be addressed. E-mail address: dlhopkins@mail. ifas.ufl.edu

${ }^{2}$ Biological Scientist.
The best control of BFB of watermelon that is currently available is to prevent the introduction of the bacterium into the field (Latin, 1996). The causal agent of bacterial fruit blotch can be seed-transmitted in watermelon (Kucharek et al., 1993; Rane and Latin, 1992; Webb and Goth, 1965). Contaminated seed lots of watermelon provide one way in which the bacterium may be introduced into a watermelon field or transplant house, where it can rapidly spread throughout the field or house (Hopkins, 1994) or field (Hopkins, 1993). The intensive efforts of the seed industry and the transplant industry to produce seeds and transplants free of $A$. avenae subsp. citrulli have reduced the incidence of BFB significantly over the last 5-6 seasons (Hopkins, unpublished). Introduction of the bacterium on contaminated seeds has been greatly reduced through improved production practices by the seed producer, fermentation and acid treatment of diploid seeds (Hopkins et al. 1996), and use of seeds from seedlots that have assayed negative for the presence of the bacterium by grow-out of at least 10,000 seedling. In spite of these efforts, the bacterium still appears in a few fields every year, and this watermelon disease was a significant problem in some states again in the 2000 season. In addition to infested seeds and infected transplants, the bacterium may invade a field from contaminated volunteer watermelons, other cultivated cucurbits, and wild cucurbits (Isakeit et al., 1998; Latin and Hopkins, 1995). The only control option for fruit blotch once it gets into a field is multiple applications of a coppercontaining bactericide (Hopkins, 1991).

While a great deal of effort has been expended to assure that watermelon seed lots are not contaminated with A. avenae subsp. citrulli, very little attention has been given to seed contamination of other cucurbits. Most of the severe losses from fruit blotch of watermelon that have occurred since 1989 have involved infected transplants. Other cucurbits, such as muskmelon and honeydew, are often grown in the same transplant houses with watermelon. A. avenae subsp. citrulli has been reported to cause disease on cucurbit crop hosts other than watermelon, including muskmelon (Cucumis melo L.) (Latin and Hopkins, 1995), honeydew (Cucumis melo L.) (Isakeit et al., 1997), and pumpkin (Cucurbita pepo L.) (Langston et al., 1999). The bacterium could rapidly spread from infected muskmelon to watermelon transplants being grown in the same transplant house. Other cucurbits often are direct-seeded adjacent to watermelon fields and, under the right conditions, field spread is rapid.

Seed transmission in these other cucurbit hosts of A. avenae subsp. citrulli needs to be evaluated and, if necessary, steps should be taken to assure that seed lots of other cucurbits are not contaminated. The objective of this study was to evaluate bacterial fruit blotch symptom development and seed transmission of A. avenae subsp. citrulli in various cucurbits.

\section{Materials and Methods}

Plant material. Eleven different commercial cucurbit cultivars were evaluated in 1997 and in 1999. Included were 'Charleston Gray' (1997) and 'Crimson Sweet' (1999) watermelon; 'Athena', 'Green Ice', and 'Saticoy' muskmelon; 'Honeybrew' honeydew melon; 'Tay Belle' acorn squash; 'Butterboy' butternut squash; 'Crescent' yellow squash; 'Senator' (1997) and 'Elite 828' (1999) zucchini squash; 'Raider' cucumber; and 'Ichabod' pumpkin.

Pathogen. A strain of A. avenae subsp. citrulli (WFB89-1) isolated in 1989 in Florida from a commercial watermelon cultivar was used throughout these tests. WFB89-1 was stored at $-70{ }^{\circ} \mathrm{C}$ in nutrient broth and was grown on nutrient agar for preparation of inoculum. Other strains obtained from commercial watermelon fields in 1989 through 1994 were similar in virulence to WFB89-1. This strain has given reproducible, severe symptoms on commercial varieties (Hopkins et al., 1993).

Field plan. Two 7.6-m rows of each cucurbit cultivar were direct-seeded in the field at a seed depth of $2.5 \mathrm{~cm}$ on 14 Mar. 1997 and on 16 Mar. 1999. Five hills of watermelon were planted per row and nine hills per row of the other cucurbits were planted on raised beds without mulch. In one row of each cultivar, 'Charleston Gray' watermelon seed infested by A. avenae subsp. citrulli were planted adjacent to the center hill $(30 \mathrm{~cm}$ from the third hill of watermelon and between the fourth and fifth hill of the other cucurbits). Seed infested with A. avenae subsp. citrulli (WFB89-1) had been obtained from 'Charleston Gray' watermelon grown at the Univ. of Florida research center in Leesburg in Spring 1993. The seed were harvested from fruit with typical symptoms of the disease. Seed transmission of BFB 
in these seed had been $>60 \%$ and was still $\approx 50 \%$. The infected watermelon plants adjacent to the center hills were removed 6 weeks after planting. This row was used to evaluate the natural development of foliar symptoms and spread on the different cucurbits. In the second row of each cultivar, individual fruit were inoculated with A. avenae subsp. citrulli. This row was used to evaluate fruit symptoms and seed transmission.

In 1997, total rainfall during the season was $20.32 \mathrm{~cm}$ and another $7.62 \mathrm{~cm}$ of water was applied in four overhead irrigations. In 1999, total rainfall during the season was $19.84 \mathrm{~cm}$, with another $11.43 \mathrm{~cm}$ applied in six overhead irrigations.

Evaluation offoliar symptom development and spread. Foliar symptoms were rated on each plant in a row using a scale based on the proportion of leaves with lesions: $1=$ no foliar symptoms; $3=$ necrotic lesions on $\approx 25 \%$ of leaves; $5=$ necrotic lesions on $50 \%$ of leaves; $7=$ necrotic lesions on $\approx 75 \%$ of leaves; and 9 $=$ necrotic lesions on most leaves. Ratings of foliar symptoms were made weekly beginning 6 weeks after planting and continuing until 2 weeks prior to harvest. Ratings for the individual plants in the row were averaged to obtain the overall rating for a cucurbit cultivar.

Spread of A. avenae subsp. citrulli from the infested watermelon seedlings to the other hills was determined by the weekly development of symptoms. Spread was scored on a $0-3$ scale where: $0=$ symptoms only on the infested watermelon or on the plants growing in the adjacent hills on either side of the infested watermelon; 1 = symptom development on the second hill from infested watermelon; 2 = development of symptoms beyond the adjacent hills but not to both ends of the row; and 3 = development of symptoms on every plant in the row.

Fruit symptoms and seed transmission. Individual fruit were inoculated $\approx 1$ week after anthesis. For inoculations, 48-h cultures of WFB89-1 on nutrient agar were washed from the agar surface with sterile, deionized water. Bacterial suspensions were adjusted to $A_{600 \mathrm{~m}}$ $=0.25$ with a spectrophotometer and diluted 100 -fold with sterile water $\left(10^{5}\right.$ to $10^{6} \mathrm{CFU} /$ $\mathrm{mL}$ ). Fruit were inoculated by misting with the bacterial suspension until runoff using a handsprayer bottle in the late afternoon.

Fruit symptoms were rated in late May and early June, immediately prior to harvest. They were rated on a $0-3$ scale, with $0=$ no fruit symptoms, $1=$ a few small necrotic lesions, 2 $=$ numerous necrotic lesions or small watersoaked lesions, and $3=$ large, spreading, water-soaked lesions or brown lesions with cracks that ooze an amber substance. For those cucurbits that developed fruit symptoms, the overall rating for the cucurbit cultivar was the average rating of the fruit with symptoms.

Mature, inoculated fruit of the various cucurbits were harvested and seeded between 2 June and 17 June 1997 and between 21 May and 11 June 1999. The surface of the harvested fruit and the knife were wiped with $95 \%$ alcohol before each fruit was cut. Seeds were collected by hand from fruit into 4-L buckets.
Seeds were cleaned by filling the buckets and floating debris from the buckets, followed by collecting the seeds on a wire screen and gently rinsing with a water hose. Seed were dried on the screens on a greenhouse bench.

For the greenhouse assay of seed transmission, random seed samples were planted in 28 $\times 52-\mathrm{cm}$ plastic trays filled with commercial potting mix. Two rows of 25 seeds were planted in each tray. When plants emerged, the seedling trays in a treatment replication (100 seedlings in 1997 and 500 seedlings in 1999) were covered with plastic domes for two nights. Seedling trays were watered carefully on the surface of the potting mix with a hose, avoiding contact with the seedlings. Greenhouse temperatures ranged from 21 to $35^{\circ} \mathrm{C}$. Disease evaluations were made $10 \mathrm{~d}$ after planting. In 1997 assays, four replications of 100 seeds per replication of each cucurbit were planted and, in 1999, four replications of 500 seeds were planted. Disease incidence was calculated based on the number of emerged seedlings.

Data analysis. Seed transmission data were subjected to analysis of variance using the general linear models (GLM) procedure of SAS (SAS Institute, Cary, N.C.). The Duncan's new multiple range test at $P=0.05$ was used for mean separation.

\section{Results}

Foliar symptoms and spread of bacterial fruit blotch. 'Charleston Gray' and 'Crimson Sweet' watermelon, 'Honeybrew' honeydew melon, and 'Saticoy' muskmelon developed fruit blotch lesions on $>50 \%$ of their leaves (Table 1). BFB spread to every plant in the row, producing similar foliar symptoms on all plants. 'Athena' muskmelon had symptoms on $25 \%$ to $50 \%$ of its leaves, but symptoms only spread to about half of the plants. Except for 'Crescent' yellow squash in 1997, the rest of the cucurbits developed foliar lesions of bacterial fruit blotch on $25 \%$ or less of the foliage and symptoms did not spread beyond the plant adjacent to the infested watermelon.

Fruit symptoms and seed transmission. Severe fruit symptoms developed on both watermelon cultivars and 'Honeybrew' honeydew melons (Table 2). Typical, large, spreading, water-soaked lesions developed on the watermelon fruit. In 'Honeybrew', symptoms consisted of numerous deep cracks, $\approx 1-2 \mathrm{~cm}$ in length and surrounded by watersoaking. Fruit of the three muskmelon cultivars ('Saticoy', 'Athena', and 'Green Ice') only had a few small necrotic lesions on the surface of the rind. A few small lesions were observed on zucchini and yellow squash as well as cucumber in 1999 but not in 1997. Fruit symptoms were not observed on fruit of acorn squash, pumpkin, or butternut squash in this test.

In 1997, seed transmission of $A$. avenae subsp. citrulli occurred in all cucurbit cultivars except 'Raider' cucumber and 'Ichabod' pumpkin (Table 2). The highest percentage of seed transmission was in 'Charleston Gray' watermelon and 'Honeybrew' honeydew melon. The seed transmission rate was greater in 'Senator' zucchini squash and 'Crescent' yellow squash, which had no fruit symptoms, than in the three muskmelon cultivars, which had fruit symptoms. Seed yield and germination were very low for 'Butterboy' butternut squash, so it was not included in the statistical analysis. However, there was seed transmission of A. avenae subsp. citrulli to 3 of 28 seedlings. Overall, seed transmission rates were lower in 1999 than 1997; however, seed transmission of $A$. avenae subsp. citrulli was observed in every cucurbit evaluated (Table 2 ). The highest rate of seed transmission again occurred in watermelon.

Table 1. Development of foliar symptoms of bacterial fruit blotch and spread of Acidovorax avenae subsp. citrulli in various cucurbits.

\begin{tabular}{lccccc}
\hline \hline & \multicolumn{2}{c}{ Foliar symptoms } & & & \multicolumn{2}{c}{ Spread of symptoms } \\
\cline { 2 - 3 } \cline { 5 - 6 } Cucurbit & 1997 & 1999 & & 1997 & 1999 \\
\hline Watermelon, 'Charleston Gray' & 7 & --- & & 3 & --- \\
Watermelon, 'Crimson Sweet' & --- & 5 & & --- & 3 \\
Honeydew, 'Honeybrew' & 7 & 6 & & 3 & 3 \\
Muskmelon, 'Saticoy' & 7 & 6 & & 3 & 3 \\
Muskmelon, 'Athena' & 5 & 3 & & 2 & 1 \\
Muskmelon, 'Green Ice' & 2 & 2 & & 0 & 0 \\
Zucchini squash, 'Senator' & 2 & --- & & 0 & --- \\
Zucchini squash, 'Elite 828' & --- & 1 & & --- & 0 \\
Yellow squash, 'Crescent' & 4 & 3 & & 1 & 0 \\
Acorn squash, 'Tay Belle' & 2 & 3 & & 0 & 0 \\
Cucumber, 'Raider' & 1 & 3 & & 0 & 0 \\
Pumpkin, 'Ichabod' & 2 & 1 & & 0 & 0 \\
Butternut squash, 'Butterboy' & 2 & 1 & & 1 & 0 \\
\hline
\end{tabular}

${ }^{2}$ Foliar symptoms were rated on each plant using a 1-9 scale based on the proportion of leaves with lesions: $1=$ no foliar symptoms; $3=$ necrotic lesions on $\approx 25 \%$ of leaves; $5=$ necrotic lesions on $50 \%$ of leaves; $7=$ necrotic lesions on $\approx 75 \%$ of leaves; and $9=$ necrotic lesions on most leaves. Ratings for the individual plants in the row were averaged to obtain the overall rating for a cucurbit cultivar.

${ }^{y}$ Spread of $A$. avenae subsp. citrulli from an infected watermelon seedlings adjacent to the center hill in a row to the other hills was determined by the weekly development of symptoms. Spread was scored on a $0-3$ scale where: $0=$ symptoms only on the infested watermelon or on the plants growing in the adjacent hills on either side of the infested watermelon; 1 = symptom development on the second hill from infested watermelon; 2 = development of symptoms beyond the adjacent hills but not to both ends of the row; and $3=$ development of symptoms on every plant in the row. 
Table 2. Fruit symptoms of bacterial fruit blotch and seed transmission of Acidovorax avenae subsp. citrulli in various cucurbits.

\begin{tabular}{lccccc}
\hline \hline & \multicolumn{2}{c}{ Fruit symptoms ${ }^{\mathrm{z}}$} & & \multicolumn{2}{c}{ Seed transmission $(\%)^{\mathrm{y}}$} \\
\cline { 2 - 3 } \cline { 5 - 6 } Cucurbit & 1997 & 1999 & & 1997 & 1999 \\
\hline Watermelon, 'Charleston Gray' & 3 & --- & & $41 \mathrm{a}$ & --- \\
Watermelon, 'Crimson Sweet' & - & 3 & & --- & $18 \mathrm{a}$ \\
Honeydew, 'Honeybrew' & 3 & 3 & & $24 \mathrm{ab}$ & $6 \mathrm{~b}$ \\
Muskmelon, 'Saticoy' & 1 & 1 & & $9 \mathrm{bc}$ & $4 \mathrm{bc}$ \\
Muskmelon, 'Athena' & 1 & 1 & & $3 \mathrm{~cd}$ & $<1 \mathrm{c}$ \\
Muskmelon, 'Green Ice' & 1 & 1 & & $<1 \mathrm{~d}$ & $1 \mathrm{bc}$ \\
Zucchini squash, 'Senator' & 0 & --- & & $10 \mathrm{bc}$ & --- \\
Zucchini squash, 'Elite 828' & --- & 1 & & --- & $2 \mathrm{bc}$ \\
Yellow squash, 'Crescent' & 0 & 1 & & $9 \mathrm{bc}$ & $3 \mathrm{bc}$ \\
Acorn squash, 'Tay Belle' & 0 & 0 & & $<1 \mathrm{~d}$ & $7 \mathrm{~b}$ \\
Cucumber, 'Raider' & 0 & 1 & & $0 \mathrm{~d}$ & $2 \mathrm{bc}$ \\
Pumpkin, 'Ichabod' & 0 & 0 & & $0 \mathrm{~d}$ & $1 \mathrm{bc}$ \\
Butternut squash, 'Butterboy' & 0 & 0 & & $(11)^{\mathrm{x}}$ & $(1)$ \\
\hline
\end{tabular}

${ }^{2}$ Fruit were inoculated $\approx 1$ week after anthesis and symptoms were rated in late May and early June, immediately prior to harvest. They were rated on a $0-3$ scale, with $0=$ no fruit symptoms, 1 = a few small necrotic lesions, 2 = numerous necrotic lesions or small water- soaked lesions, and $3=$ large, spreading, water-soaked lesions or brown lesions with cracks.

yercentage of seed transmission of Acidovorax avenae subsp. citrulli was determined by a greenhouse grow out of seedlings. A total of 400 seeds of each were evaluated in 1997 and 2000 of each in 1999. Mean separation within columns by Duncan's new multiple range test, $P=0.05$ level.

${ }^{x}$ Because of poor seed production and germination, butternut squash was not included in the replicated test. Value is based on 28 seedlings in 1997 and 168 seedlings in 1999.

\section{Discussion}

In addition to watermelon, A. avenae subsp. citrulli has caused disease in commercial crops of muskmelon (Latin and Hopkins, 1995), honeydew melon (Isakeit et al., 1997), and pumpkin (Langston et al., 1999). However, the demonstration in this study that seed transmission of A. avenae subsp. citrulli occurred in nine different cucurbits, even though there may be no fruit symptoms, illustrates that all cucurbit crops must be included in the control strategies for bacterial fruit blotch. Any cucurbit crop being grown in the same transplant house or field is a potential source of the bacterium for infection of cucurbits on which disease loss can occur, such as watermelon, muskmelon, and honeydew.

While seed transmission was detected in all cucurbits tested when the bacteria was either misted onto the surface of the fruit or, through overhead irrigation and rainfall, was splashed onto the fruit from adjacent infected watermelon plants, the chance of seed transmission occurring in commercial seed should be greater in cucurbits on which foliar symptoms can develop and on which $A$. avenae subsp. citrulli spreads. In these susceptible crop cucurbits, such as watermelon, honeydew, and muskmelon, there is potentially a larger reservoir of bacteria on the foliage to be splashed onto the fruit and contaminate the seed. In contrast, several of the cucurbit types developed foliar symptoms only on plants immediately adjacent to infected watermelon plants where the bacterial reservoir on the watermelon foliage could splash directly onto the other cucurbit. When seed production fields of these cucurbits are grown, reservoirs of $A$. avenae subsp. citrulli should not develop on the foliage to infest the fruit even if the bacterium was introduced into the field. Thus, the chances of seed transmission of $A$. avenae subsp. citrulli in commercial seed of acorn, yellow, or zucchini squash, cucumbers, or pumpkin should be lower than in watermelon, honeydew, or muskmelon. However, there is always the possibility of a low level of seed transmission from introduced bacteria in any cucurbit.

With most of the cucurbits, only a single cultivar was evaluated and there can be differences in susceptibility among cultivars. Foliage of other cultivars of squash, cucumber, or pumpkin could develop symptoms that spread and result in a greater chance of seed transmission. In this test for example, 'Saticoy' muskmelon foliage appeared more susceptible than 'Athena', which was more susceptible than 'Green Ice'. DNA fingerprinting and whole cell fatty acid analysis has demonstrated that A. avenae subsp. citrulli strains differ genetically and separate into two distinct groups (Walcott et al., 2000). We did not evaluate any strains from group I, which includes strains originally from cantaloupe and pumpkin, but used a typical watermelon strain (group II). Squash, cucumber, and pumpkin could be more susceptible to a group I strain.

Based on our results, any cucurbit crop plant should be considered a potential source of primary inoculum of $A$. avenae subsp. citrulli for that crop and any other cucurbit grown in the same transplant house or field. Control strategies should be adjusted accordingly. For example, all cucurbit seed production fields should be isolated from any other cucurbit field and observed frequently for foliar symptom of fruit blotch. If possible, seedlots of all cucurbits should be assayed for the presence of A. avenae subsp. citrulli, especially watermelon, honeydew, muskmelon, and any cucurbit in which symptoms (typical or atypical of fruit blotch) were observed. If possible, use "dedicated" transplant house for a single seedlot, variety, or cucurbit type. Growers should isolate watermelon fields from other cucurbits.

\section{Literature Cited}

Hopkins, D.L. 1991. Chemical control of bacterial fruit blotch of watermelon. Proc. Fla. State Hort. Soc. 104:270-272.

Hopkins, D.L. 1993. Field spread of bacterial fruit blotch of watermelon. Phytopathology 83:466. (Abstr.)

Hopkins, D.L. 1994. Spread of bacterial fruit blotch of watermelon in the greenhouse. Phytopathology 84:775. (Abstr.)

Hopkins, D.L., J.D. Cucuzza, and J.C. Watterson. 1996. Wet seed treatments for the control of bacterial fruit blotch of watermelon. Plant Dis. 80:529-532.

Hopkins, D.L., C.M. Thompson, and G.W. Elmstrom. 1993. Resistance of watermelon seedlings and fruit to the fruit blotch bacterium. HortScience 28:122-123.

Isakeit, T., M.C. Black, L.W. Barnes, and J.B. Jones. 1997. First report of infection of honeydew with Acidovorax avenae subsp. citrulli. Plant Dis. 81:694.

Isakeit, T., M.C. Black, and J.B. Jones. 1998. Natural infection of citron melon with Acidovorax avenae subsp. citrulli. Plant Dis. 82:351.

Kucharek, T., Y. Perez, and C. Hodge. 1993. Transmission of the watermelon fruit blotch bacterium from infested seed to seedlings. Phytopathology 83:466. (Abstr.)

Langston, Jr., D.B., R.R. Walcott, R.D. Gitaitis, and F.H. Sanders, Jr. 1999. First report of a fruit rot of pumpkin caused by Acidovorax avenae subsp. citrulli in Georgia. Plant Dis. 83:199.

Latin, R.X. 1996. Bacterial fruit blotch, p. 34-35. In T.A. Zitter, D.L. Hopkins, and C.E. Thomas (eds.). Compendium of cucurbit diseases. APS Press, St. Paul, Minn.

Latin, R.X. and D.L. Hopkins. 1995. Bacterial fruit blotch of watermelon: The hypothetical exam question becomes reality. Plant Dis. 79:761765.

Latin, R.X. and K.K. Rane. 1990. Bacterial fruit blotch of watermelon in Indiana. Plant Dis. 74:331.

Maynard, D.N. and D.L. Hopkins. 1999. Watermelon fruit disorders. HortTechnology 9:155161.

Rane, K.K. and R.X. Latin. 1992. Bacterial fruit blotch of watermelon: Association of the pathogen with seed. Plant Dis. 76:509-512.

Somodi, G.C., J.B. Jones, D.L. Hopkins, R.E Stall, T.A. Kucharek, N.C. Hodge, and J.C. Watterson. 1991. Occurrence of a bacterial watermelon fruit blotch in Florida. Plant Dis. 75:1053-1056.

Walcott, R.R., D.B. Langston, Jr., F.H. Sanders, Jr., and R.D. Gitaitis. 2000. Investigating intraspecific variation of Acidovorax avenae subsp. citrulli using DNA fingerprinting and whole cell fatty acid analysis. Phytopathology 90:191-196.

Webb, R.E. and R.W. Goth. 1965. A seedborne bacterium isolated from watermelon. Plant Dis. Rpt. 49:818-821. 